\title{
The Entrepreneurial University: How to Develop the Entrepreneurial Orientation of Academia
}

\author{
Rosangela Feola $^{1} \cdot$ Roberto Parente $^{1} \cdot$ Valentina Cucino $^{2}$
}

Received: 7 April 2017 / Accepted: 20 July 2020 / Published online: 30 September 2020

(C) The Author(s) 2020

\begin{abstract}
In the last years, universities have assumed a prominent role in the science and technologybased economic development. The concept of entrepreneurial university, a key concept in the triple helix model developed by Etzkowitz, identifies the evolution of the university role with the addition to the traditional missions of university (education and research) of a third mission that is to contribute to the economic development through the transfer of research results from the laboratory to the economic system. The objective of the research is to analyze how universities are implementing this new mission and investigate factors affecting their entrepreneurial orientation. More specifically, our paper aims to investigate the existence of a relationship among the entrepreneurial orientation of university and some factors representing the internal and external context in which the university is involved.
\end{abstract}

Keywords Triple helix · Entrepreneurial university - Technology transfer - Entrepreneurial orientation $\cdot$ Internal and external context

\section{Introduction}

In the last years, universities have assumed a prominent role in the science and technology-based economic development, and the entrepreneurial university is largely

Rosangela Feola

rfeola@unisa.it

Roberto Parente

rparente@unisa.it

Valentina Cucino

valentina.cucino@santannapisa.it

1 Department of Management and Innovation Systems, University of Salerno, Via Giovanni Paolo II, 132, 84084 Fisciano, SA, Italy

2 Scuola Superiore Sant'Anna - Institute of Management and Department EMbeDS, Piazza Martiri della Libertà, 33, 56127 Pisa, Italy 
recognized as a key actor of competitiveness, economic growth, and wealth creation in the modern world (Fayolle and Redford 2014; Mian 2011).

The concept of entrepreneurial university, a key concept in the triple helix model developed by Etzkowitz (1993), identifies the evolution of the university role with the addition to the traditional missions of the university (education and research) of a third mission that is to contribute to the economic development through the transfer of research results from the laboratory to the economic system.

This new role for university, from one hand, involves a radical change in the internal organization and activities carried out by academic institutions (Etzkowitz et al. 2000, 2019), from the other, can be carried out through different mechanisms such as patents, licenses, research joint ventures, and the creation of academic spin-off companies (Lockett et al. 2005; Fuster et al. 2019; Petruzzelli and Murgia 2019; Feldman et al. 2019).

As highlighted by several authors (Guerrero et al. 2016a, b; Klofsten et al. 2019; Phillips 2018), the model of entrepreneurial university is a complex phenomenon, which includes different academic traditions, decision-making levels, research values, and sub-organizational cultures. In this perspective, the concept of entrepreneurial university has been explored with specific reference to different contexts and in different countries (Dalmarco et al. 2018: Elia et al. 2017; Riviezzo et al. 2017; Sperrer et al. 2016). A lot of attention has been paid to the understanding of the transformation of the university's role in European regions (Dabić 2019; Mosey et al. 2017), also in consideration of the Etzkowitz' suggestion (2003b) of the European context as an alternative to the US model.

Most of the research on entrepreneurial universities has tackled the subject from an operational point of view, studying knowledge transfer offices (Fernandez-Alles et al. 2018; Muscio 2010), collaboration between companies and universities (D'Este and Perkmann 2011; Dooley and Kirk 2007), support for innovation (Etzkowitz 2003a; Holden and Goldstein 2010), development of new spin-off companies (Harrison and Leitch 2010; O'Shea et al. 2005), and incubators and science parks (Grimaldi and Grandi 2001; Mian 1994).

Several authors have tried to explain the phenomenon of entrepreneurial universities (Clark 1998; Etzkowitz et al. 2019; O'Shea et al. 2005). The models developed in the literature generally distinguish between external (Clark 1998; Sporn 2001; Etzkowitz 2004; Kirby 2005; Rothaermel et al. 2007; Guerrero et al. 2016a, b) and internal factors (O'Shea et al. 2005, 2008; Rothaermel et al. 2007; Sànchez-Barrioluengo and Benneworth 2019) influencing the development of entrepreneurial university. However, few theoretical frameworks have been proposed to analyze the interrelations among different factors (Guerrero et al. 2016a, b; Guerrero 2008), and at the best knowledge of the authors, few empirical studies have investigated the interrelations among environmental and internal factors that influence the development of entrepreneurial universities (see for example Guerrero and Urbano 2012).

Building on these premises, the objective of the research is to analyze how universities are implementing this new mission exploring how internal dynamic and external dynamic factors affect the entrepreneurial orientation of university.

More specifically, our paper aims to investigate the existence of a relationship among the entrepreneurial orientation of university and the quality of university 
research and the rate of innovativeness of the region in which the university is involved, representing, respectively, internal and external context.

In order to reach this aim, the research is structured in two phases. In the first one, we develop an index to measure the capability of the university to promote economic and entrepreneurial exploitation of academic research. In the second step, we compare this entrepreneurial attitude index (EAI), composed by input factors (concerning activities and instruments promoted to stimulate entrepreneurial spirit in universities) and by output factors (concerning the results of such activities) with other kinds of academic-based and economic-based indexes in search of potential explanations of universities ranking status.

The research focuses on Italy, where the concept of the entrepreneurial university is now a generally accepted concept showing results that start to be interesting but yet lower compared with results obtained by North European or North American universities (Cesaroni et al. 2005; Riviezzo and Napolitano 2010; Balderi et al. 2012).

Our research has theoretical and practical implications. From a theoretical point of view, the study contributes to a better understanding of the most critical factors that influence the third mission of the university. From a practical point of view, the study could help universities and policy makers in the adoption of adequate measures able to promote and support the entrepreneurial mission of academia.

The paper is structured as follows. "The Theoretical Frame of Reference" section discusses the theoretical framework of entrepreneurial university. The "Research Design" section introduces the research design, the methodology, and results. The "Discussion and Conclusion" section discusses the results of the research. The "Implications and Future Research" section draws some implications of the study and outlines directions for future research.

\section{The Theoretical Frame of Reference}

\section{Entrepreneurial University: Mechanisms of Technology Transfer and Support Systems}

The role of the universities for social and economic development is, in more recent years, a very relevant topic among researcher and policy makers. The concept of entrepreneurial university (Etzkowitz 1993) identifies the evolution of the university role with the addition to the traditional missions of education and research of a third mission that is to contribute to the economic development through the transfer of research results from the laboratory to the economic system. In actual economic systems, the entrepreneurial university is largely recognized as a key actor of competitiveness, economic growth, and wealth creation (Fayolle and Redford 2014; Mian 2011).

The phenomenon of entrepreneurial universities has been explored from two separate but strictly related aspects. From one hand, the different mechanisms through which technology transfer processes could be put in place have been investigated; on the other hand, policies and instruments promoted by universities to support technology transfer processes have been analyzed.

The concept of technology transfer is a broad concept that includes several mechanisms that can be classified mainly on the basis of the type of transferred knowledge. 
Different ways of technology transfer are classified as (Cesaroni and Gambardella 2001; Bradley et al. 2013):

- Codified transfer directed to the exploitation and valorization of patents' portfolio that is research results that can be codified and legally protected (Banga and te Velde 2019; Kim et al. 2017). These mechanisms include patents and their licensing or transfer to a company. The patent can be licensed (with exclusive or not) to a company, with the consequence of generating revenue for the university and to develop the research at the application stage. The patent may also be transferred to a company or to a spin-off, which is connected in various ways to the university, involving in this way the same researchers who carried out the research;

- Tacit transfer mechanisms directed to the exploitation and valorization of knowledge asset developed by a researcher (Joia and Lemos 2010). These mechanisms include the creation of start-up and spin-off, participation in research projects, and consulting activities (Lee 2020).

Among different mechanisms of technology transfer, a growing attention has been devoted in the last years to the creation of academic spin-off, a specific and economically powerful group of new technology-based firms (Shane and Stuart 2002; Heirman and Clarysse 2004; Bengoa et al. 2020) founded by academic researchers with the aim to exploit technological knowledge that originated within a university (Bonaccorsi and Daraio 2007). This definition highlights the main characteristics of academic spin-off, concerning two main aspects:

- the founders' profile that are subjects coming from a research context with a background and set of rules very different from the entrepreneurial context (Clarysse and Moray 2004; Fryges and Wright 2014);

- the nature and characteristics of the technology they are based on (Shane 2004) that generally are technologies that introduce radical innovations, having general purpose applications and with a predominant component of tacit knowledge.

Academic spin-offs are increasingly recognized for their contribution to the national economy in terms of support to economic and technological growth (Di Gregorio and Shane 2003; Roberts and Malone 1996; Roberts 1991; Shane 2004; Carlesi et al. 2017), creation of new jobs (Perez and Sánchez 2003; Steffensen et al. 2000; Rizzo 2015), and contribution to the regional development (Mian 1996; Trequattrini et al. 2015).

In the evaluation of evolution toward the entrepreneurial university, the different mechanisms through which technology transfer is realized, represent only one side of the coin. The development of the third mission of university, in fact, can be analyzed considering measures and strategy developed by the university with the aim to encourage and support technology transfer processes.

With the aim of supporting technology transfer processes and to assume a leading role in the economic development, in the last years, many universities have promoted policies and specific supporting activities to academic researchers. The set of support mechanisms that universities have developed is quite varied depending on the phase of 
intervention, the subject targeted, the type of support provided, the nature, and type of resources mobilized (Fini et al. 2011).

A first set of policies, represented by the organization of events or courses on the specific theme of entrepreneurship, is targeted at the diffusion of an entrepreneurial culture among faculty and students. In the last years in fact, starting from the idea that the development of entrepreneurial attitudes and skills can be encouraged in young people starting from school and education (European Commission 2002; Clark 2004; Gibb 2005; Fayolle 2007), the theme of entrepreneurship education has received increasing attention from researcher (Ranga et al. 2003; Jacob et al. 2003; Schulte 2004; Guerrero and Urbano 2007; Stokes and Wilson 2010; Napolitano and Riviezzo 2008; Riviezzo and Napolitano 2010; Barba-Sánchez and Atienza-Sahuquillo 2018). Further, many universities have offered an increasing number of institutional courses dedicated to entrepreneurship culture and development not only on the undergraduate level but also on the post-graduate courses (such as the Academic Master, the PhD Programme) and on all the other extra-curricular activities (such as the specialization courses, the vocational training) (Riviezzo and Napolitano 2010; Duval-Couetil 2013; Turner and Gianiodis 2018).

Also in Italy, recent studies show that the number of courses dedicated to entrepreneurship is growing in multidisciplinary environment (Fiore et al. 2019). However, the situation is very distant from that shown by countries with a more historical tradition (Riviezzo and Napolitano 2010).

A second set of policies is directed to increase the entrepreneurial spirit of academic researchers and their awareness about the possibilities of starting a new business and pursuing an entrepreneurial career (Mustar and Wright 2010). Among these, there are initiatives such as business plan competitions and technology transfer services (Parente et al. 2015; Siegel et al. 2007). In the last years, start-up competitions are booming all over the world. In Italy too in the last few years, new start-up competitions have been added to the oldest one. The business plan competitions could represent the first test for academic entrepreneurial projects. These initiatives, on the one hand, represent the first time for researchers to convert their own research in an entrepreneurial project, on the other, they represent a window through which to communicate the project to community and potential investors (Parente et al. 2015).

University incubators, another kind of policies aimed to stimulate and support technology transfer processes, on the other side are booming (Mian 1996; Rothaermel and Thursby 2005). In addition to the typical incubator services (shared office services, business assistance, access to capital, business networks, etc.), university incubators offer some university-related services, such as faculty consultants, student employees, library services, and access to R\&D facilities (Mian 1996; Von Zedtwiz and Grimaldi 2006).

Another policy directly targeted at providing specific resources to academic spin-off is the institution of university venture funds, fully or partly funded by university resources, and generally acting at the seed and start-up stages (Fini et al. 2011).

In order to offer support to academic spin-offs and in more general terms to researchers, many universities have promoted the creation of technology transfer office (TTO). Technology transfer offices have been generally included in the university organizational structure but sometimes have been established as an independent structure outside the university, but operating in its name, with the common aim to facilitate 
the passage of knowledge and know-how from academia to business (Good et al. 2019).

\section{Entrepreneurial University and Triple Helix Model}

The concept of entrepreneurial university is a central concept of the triple helix model developed by Etzkowitz (1993) and Etzkowitz and Leydesdorff (1995). The triple helix model is based on the idea that the potential for innovation and economic development, in a knowledge society, lies in a more prominent role for the university and in the collaboration and hybridization of the three pillars of the virtuous circle of innovation: university, industry, and government.

The triple helix model is based on three basic elements (Etzkowitz et al. 2007):

- A new role for university in the development process of innovation;

- The development of collaborations among the three helices;

- The idea that each actor in addition to its traditional functions assumes the roles of others.

In the triple helix model, each actor of the system has to play a specific role but should work in close synergy with the others:

- universities produce new knowledge and technologies that can have an industrial application;

- government acts as a public entrepreneur in addition to its traditional regulatory role in setting the rules of the game;

- venture capital and large companies act as engines of innovative system, bringing capital, managerial skills, and a network of relationships that foster the development of innovative businesses.

Government plays a central role in the creation of the necessary conditions for an effective commercialization of research results. Government can provide support in two different ways: defining the set of rules and normative conditions for the implementation of entrepreneurial activities and by providing physical and financial support for entrepreneurs (such as loans, incubators, science parks) (Fini et al. 2011; Feldman 2001).

In the last years, several countries have promoted legislative reforms aiming to stimulate technology transfer processes from university to economic system (Fini et al. 2011) and with the general objective to overcome the market failure in the innovations processes (Martin and Scott 2000).

The Bayh-Dole Act emanated in the USA in 1980 and similar legislative instruments adopted during the 1990s in some European countries (i.e., France, UK) have been considered key elements in the development of entrepreneurial activities of subjects generally involved in research activities (Roberts and Malone 1996; Shane 2004).

In Italy too, also if only in more recent years, Government with the National Law of 1999 (Law 297 del 1999) has provided the legislative framework for 
academic spin-offs in addition to financial support for this particular kind of innovative start-ups.

More recently, in 2012, the innovative start-up law has introduced a specific discipline for this kind of firms in order to stimulate the creation and development.

The role of government also includes the provision of financial incentives and physical infrastructures such as incubators, science parks (Feldman 2001), that have been shown as key elements in fostering entrepreneurship and innovative start-ups.

Industry and finance can provide important resources for the establishment and growth of academic spin-offs and in more general terms for the exploitation of research results (Fini et al. 2011; Etzkowitz 2017). Venture capital plays a critical role in the development of innovative firms, through the direct financial support provided by capital investments, and the additional support, in terms of competences and networking resources typically attached to early stage investments. The role of venture capital for the development of innovative start-ups is well recognized in the context of entrepreneurship literature. Some studies have shown the positive impact of venture capital in terms of growth in R\&D investments and number of patents (Kortum and Lerner 1998), professionalization of start-up (Hellmann and Puri 2002), and access to knowledge-based resources (Parente and Cerrato 2002).

In addition to financial support, also characteristics of the industries present in the local context can stimulate the creation of start-ups (Klepper 2007).

The presence in the local context of firms operating in the same or related sectors can facilitate the exchange of information and knowledge and the creation of relationship among firms gives access to the proximity advantage (Deeds et al. 1998). Firms operating in the local context are potential partners of academic spin-off or academic researcher in the valorization processes of their results. O'Shea et al. (2007) in their studies on spin-offs from MIT found that, in the medical-related industries, the presence of high technology clusters facilitated the creation of academic spin-offs. In these clusters, in fact, founders are able to interact with their customers and suppliers more easily and at lower cost than spin-offs from universities located in places with fewer high technology companies.

University, the third actor of the triple helix model, has to promote technology transfer processes and the exploitation of results of academic research. In doing so, they have to act in a more entrepreneurial way combining the more traditional functions of teaching and researching with a new role in the economic development, through specific forms of technology transfer and economic exploitation of research results (Brett et al. 1991; Blair and Hitchens 1998; Piccaluga 2001; Bonaccorsi and Daraio 2007).

\section{Research Design}

\section{Methodology}

In order to become more entrepreneurial, a change of mentality and operation is required to the universities. A change that, without affecting the historical mission of education and research, puts in place the conditions for a more effective and rapid exploitation of research results. At the same time, further factors, both internal and external to the university, are necessary conditions for the development of an 
entrepreneurial university (Guerrero et al. 2016a, b; Guerrero 2008; Guerrero and Urbano 2012). As highlighted by some authors, possible factors influencing the ability of university to commercialize knowledge, could be identified in the amount of research and activities realized in the region (Mueller 2006).

Starting from this consideration, the objective of the paper is to analyze the impact of some internal and external factors in the development of entrepreneurial university.

More specifically, our paper aims to investigate the existence of a relationship among the entrepreneurial orientation of university and the quality of university research and the rate of innovativeness of the region in which the university is involved, representing, respectively, internal and external context.

In doing that, we tried to answer to the following research questions:

1. There exists a relation between entrepreneurial orientation and research capability of university?

2. There is a relation between entrepreneurial orientation and the innovation capability of the regional context in which university is involved?

The paper is based on the Italian context in which the number of universities involved in technology transfer processes and offering support to promote these processes is growing in recent years but results obtained are very different among universities and regions (Netval 2018). Italy is one of the countries that has invested heavily in creating an ecosystem favorable to the entrepreneurial university (Algieri et al. 2013; Elia et al. 2017; Muscio et al. 2016) both from a practical and a legislative (Muscio 2010) point of view. From a legislative point of view, since 1999 (Legislative Decree 297/1999), Italy has given universities autonomy to establish rules and create favorable conditions for knowledge transfer activities. Through this autonomy, many Italian universities have created internal regulations establishing rules for university-industry interaction, with particular reference to the creation and management of spin-off companies and contractual research (Muscio et al. 2016). From an empirical point of view, the need to share best practices combined with the need for training of technology transfer professionals, has led to the establishment of the Italian network for the valorization of public research (Netval), which annually performs a survey of Italian universities, public research organizations, and research hospitals to monitor their technology transfer activities.

The research follows a two-step approach. In the first step, in order to measure the capability and effectiveness of university to promote and lead technology transfer processes, we develop an index that we call entrepreneurial attitude index (EAI). This entrepreneurial attitude index (EAI) is composed by input factors (concerning activities and instruments promoted to stimulate entrepreneurial spirit in universities) and by output factor (concerning the results of such activities).

The EA index considers the following 5 factors:

- The number of patents obtained from the university in the period 2004/2010;

- The number of spin-offs accredited from the university in the same period;

- The presence or absence of academic incubators;

- The amount of consulting or research contracts with external organizations;

- The number of consortium and associations participated by a university aiming to promote the technology transfer. 
The data for the construction of the index are based on secondary sources. More specifically, to build our index, we consider the results of the research quality evaluation (VQR) 2004-2010 (the last data set available) aiming to evaluate the results of scientific research carried out in the period from 2004 to 2010 from public and private universities, public research institutes supervised by the Ministry of Education, and other public and private research organizations. The VQR report follows a pattern also observed in other countries and is based on a selected subset of products. The data for the report are collected on the basis of criteria common to all public and private universities and public research institutes.

Starting from the data collected by Anvur concerning the so-called third mission of university, we integrated that data with data collected from others secondary sources (websites of universities and survey Netval, the Italian association for the valorization of public research), concerning activities and initiatives promoted and realized by universities to stimulate the valorization of research. In the construction of EA index, each factor has been considered with different weights: in particular, the number of spin-offs and incubators has a weight of 0.3 ; numbers of patents 0.2 ; contract research and consortium have a weight of 0.1 .

Finally, in order to eliminate effects due to different dimensions of universities, we consider a factor of normalization represented by the ratio between the number of fulltime subjects of the university and the total of Italian universities.

In the second step of the research, with the aim to analyze factors influencing the entrepreneurial orientation of university, we compare the EA index with other indexes that could be considered as expression of internal and external factors able to influence the entrepreneurial orientation:

- the quality of research;

- the innovativeness of the regions in which the university is located.

The quality of research has been evaluated using the academic ranking of university provided by the Anvur, the National Agency for the Evaluation of Universities and Research Institutes, that periodically provides a rank of Italian universities and research systems (Anvur 2013).

In order to measure the innovativeness of the territory on which the university is located, the regional innovation scoreboard, a regional extension of the European innovation scoreboard (the methodology applied by the European Commission since 2001 to analyze the innovation performance of European Union States in the context of Lisbon Strategy), has been used (EU, Regional Innovation Scoreboard 2014).

\section{Research Results}

The results obtained in the first step of the research show large differences among Italian universities in terms of entrepreneurial activities and results.

The EA index of the first ten Italian universities is showed in the following table (Table 1):

The University Sant'Anna of Pisa shows the higher EA index followed at long distance by Piemonte Orientale and the University Sissa of Trieste. At the fourth and fifth position of the ranking list, we find two south universities: University of Salento 
Table 1 The EA index of first ten Italian universities

\begin{tabular}{ll}
\hline Università & EAI \\
\hline Pisa S.Anna & 17.95980 \\
Piemonte Orientale & 5.11440 \\
Trieste SISSA & 3.90835 \\
Salento & 3.66766 \\
Sannio & 2.33117 \\
Torino Politecnico & 2.32691 \\
Siena & 2.26959 \\
Udine & 2.25255 \\
Ferrara & 2.23221 \\
Pisa & 1.96569 \\
\hline
\end{tabular}

and University of Sannio. The Polytechnic of Torino ranks sixth, followed by University of Siena, University of Udine, University of Ferrara, and University of Pisa.

Analyzing the 3 indicators with the higher weight that compose the EA index (patents, spin-offs, incubators), results that with the exception of the University Sant'Anna of Pisa other universities show a focus only in specific subjects.

In particular, analyzing the patents' ranking list, among the top ten, we find also the Polytechnic of Milan, the University of Salerno, and the University of Padova (Table 2).

The spin-off ranking list shows the presence of 4 new universities: University of Foggia, Perugia, Camerino, and Ancona (Table 3).

Finally, in the incubator ranking list, we find 3 new universities: University of Firenze, Bologna, and Milano (Table 4).

In the second step of the research, we compare the results obtained in the first step with the two indexes selected as measures of the quality of research and the innovativeness of territory in which university is located.

Table 2 The patent ranking list

\begin{tabular}{llll}
\hline Università & ITMS2 x w x 100 & SVETP/SVETP TOT. (\%) & EAI - patents \\
\hline Pisa S.Anna & 5.94925 & 0.13711 & 43.39034352 \\
Trieste SISSA & 0.8744 & 0.10852 & 8.057500921 \\
Pisa Normale & 0.60832 & 0.15076 & 4.035022552 \\
Udine & 3.61408 & 1.24312 & 2.90726559 \\
Siena & 3.77338 & 1.62522 & 2.321765669 \\
Milano Politecnico & 5.05235 & 2.20032 & 2.296188736 \\
Salerno & 3.51862 & 1.70125 & 2.068255694 \\
Ferrara & 2.06585 & 1.09756 & 1.882220562 \\
Torino Politecnico & 2.55185 & 1.42442 & 1.791501102 \\
Padova & 6.22777 & 3.73001 & 1.669638955 \\
\hline
\end{tabular}


Table 3 The spin-off ranking list

\begin{tabular}{llll}
\hline Università & ITMS3 x w x 100 spin-off & SVETP/SVETP TOT. (\%) & EAI \\
\hline Pisa S.Anna & 1.02029 & 0.13711 & 7.441397418 \\
Piemonte Orientale & 3.56572 & 0.64138 & 5.559449936 \\
Trieste SISSA & 0.50188 & 0.10852 & 4.624769628 \\
Salento & 4.49691 & 1.18983 & 3.779455889 \\
Foggia & 2.2555 & 0.61734 & 3.653578255 \\
Perugia & 6.15855 & 1.92479 & 3.1995958 \\
Udine & 3.86571 & 1.24312 & 3.109683699 \\
Siena & 5.02031 & 1.62522 & 3.089003335 \\
Camerino & 1.56703 & 0.52766 & 2.969772202 \\
Marche (Ancona) & 2.35275 & 0.89091 & 2.640839142 \\
\hline
\end{tabular}

Analyzing the academic ranking of Italian universities (Table 5), we find that five universities of entrepreneurial attitude top ten ranking (Table 1) are also on the top of academic ranking for the quality of research (Italics emphasis in Table 5). The others' excellent entrepreneurial universities are not in the first positions for the quality of research and are positioned in more down position of the research ranking (Table 5).

Analyzing the innovative capacity of regional context based on the regional innovation scoreboard 2014, we highlight that, in 2010, with the exception of Piemonte, Friuli-Venezia Giulia, and Emilia-Romagna classified as follower, all other Italian regions rank as moderate innovator (Table 6).

Comparing this ranking with the entrepreneurial ranking, we can observe that 5 universities (Piemonte Orientale, Trieste Sissa, Politecnico di Torino, Udine, Ferrara) out of 10 are located in the 3 regions classified as follower innovators, while the other 5 of the top ten entrepreneurial universities are located in regions classified as moderator innovators.

Table 4 The incubator ranking list

\begin{tabular}{llll}
\hline Università & ITMS4 x w x 100 & SVETP/SVETP TOT. (\%) & EAI \\
\hline Pisa S.Anna & 2.79117 & 0,13711 & 20.35715849 \\
Piemonte Orientale & 6.43262 & 0.64138 & 10.02934298 \\
Salento & 9.76617 & 1.18983 & 8.208038123 \\
Sannio & 1.25791 & 0.32491 & 3.871564433 \\
Firenze & 13.22358 & 3.45123 & 3.831555706 \\
Torino Politecnico & 5.33316 & 1.42442 & 3.744092332 \\
Pisa & 10.40235 & 2.78841 & 3.730566882 \\
Ferrara & 4.0618 & 1.09756 & 3.700754401 \\
Bologna & 14.46737 & 5.05761 & 2.860515145 \\
Milano & 10.55095 & 3.89247 & 2.710605348 \\
\hline
\end{tabular}


Table 5 Academic ranking of Italian universities

\begin{tabular}{lll}
\hline Ranking-big universities & Ranking-medium universities & Ranking-small universities \\
\hline Padova & Trento & Pisa S.Anna \\
Milano Bicocca & Bolzano & Pisa Normale \\
Verona & Ferrara & Roma LUISS \\
Bologna & Milano San Raffaele & Trieste SISSA \\
Pavia & Piemonte Orientale & Roma Biomedico \\
Torino & Venezia Cà Foscari & Aosta \\
Modena e Reggio Emilia & Bergamo & Lucca - IMT \\
Parma & Brescia & Napoli Benincasa \\
Roma Tor Vergata & Milano Bocconi & Benevento - Giustino Fortunato \\
Milano & Sannio & Bra - Scienze Gastronomiche \\
Milano Politecnico & Teramo & Castellanza LIUC \\
Pisa & Foggia & Roma Europea \\
Torino Politecnico & Macerata & Roma LUSPIO \\
Chieti e Pescara & Milano IULM & Roma UNITELMA \\
Roma Tre & Marche & Perugia Stranieri \\
\hline
\end{tabular}

Source: our elaboration of Anvur 2013

Analyzing the ranking of single indicators that compose the regional innovation scoreboard (Table 7) and in particular the following: R\&D expenditure in the public sector, R\&D expenditure in the business sector, innovative SMEs collaborating with others, SMEs introducing product or process innovation, employment in knowledgeintensive activity, we can highlight a strong link between entrepreneurial attitude and two of that indicators that are SMEs introducing product or process innovation and employment in knowledge-intensive activity. In fact, for the first one, 6 out of 7 of the first ten regions in the EA ranking are also in that ranking; for the second indicators, 5 out of 7 regions are in the relative ranking.

\section{Discussion and Conclusion}

Universities all over the world are becoming increasingly entrepreneurial by offering not only educational programs but also by considering themselves as important players within the ecosystem of innovation and economic and social development (Etzkowitz and Leydesdorff 2000; Etzkowitz 2019). Universities are important social institutions for generating and transmitting knowledge, providing platforms and instruments for support technology transfer processes, mobilizing values for entrepreneurial careers, and supporting business start-ups.

However, with this change of the universities' self-conception from being a place for research and education to being a facilitator and enabler for the generation of ideas and the application of discoveries, serious discussions have aroused on the management and really effectiveness of study programs, technology transfer offices, and incubators. 
Table 6 Italian regions' ranking

\begin{tabular}{|c|c|c|c|c|c|}
\hline & & 2004 & 2006 & 2008 & 2010 \\
\hline IT & Italy & Follower & Follower & Follower & Follower \\
\hline ITC1 & Piemonte & Moderate & Moderate & Moderate & Moderate \\
\hline ITC2 & Valle d'Aosta/Vallée d'Aoste & Moderate & Moderate & Moderate & Moderate \\
\hline ITC3 & Liguria & Moderate & Moderate & Moderate & Moderate \\
\hline ITC4 & Lombardia & Moderate & Moderate & Moderate & Moderate \\
\hline ITH1 & Provincia Autonoma Bolzano/Bozen & Moderate & Moderate & Moderate & Moderate \\
\hline ITH2 & Provincia Autonoma Trento & Moderate & Moderate & Moderate & Moderate \\
\hline ITH3 & Veneto & Moderate & Moderate & Moderate & Moderate \\
\hline ITH4 & Friuli-Venezia Giulia & Moderate & Moderate & Moderate & Follower \\
\hline ITH5 & Emilia-Romagna & Moderate & Moderate & Moderate & Follower \\
\hline ITI1 & Toscana & Moderate & Moderate & Moderate & Moderate \\
\hline ITI2 & Umbria & Moderate & Moderate & Moderate & Moderate \\
\hline ITI3 & Marche & Moderate & Moderate & Moderate & Moderate \\
\hline ITI4 & Lazio & Moderate & Moderate & Moderate & Moderate \\
\hline ITF1 & Abruzzo & Moderate & Moderate & Moderate & Moderate \\
\hline ITF2 & Molise & Modest & Modest & Moderate & Moderate \\
\hline ITF3 & Campania & Moderate & Moderate & Moderate & Moderate \\
\hline ITF4 & Puglia & Moderate & Moderate & Moderate & Moderate \\
\hline ITF5 & Basilicata & Moderate & Moderate & Moderate & Moderate \\
\hline ITF6 & Calabria & Modest & Modest & Moderate & Moderate \\
\hline ITG1 & Sicilia & Moderate & Moderate & Moderate & Moderate \\
\hline ITG2 & Sardegna & Moderate & Moderate & Moderate & Moderate \\
\hline
\end{tabular}

Source: EU, Regional Innovation Scoreboard (2014)

Our research explores how internal dynamic and external dynamic factors affect the entrepreneurial orientation of the university. The paper analyzes the existence of a relationship between the entrepreneurial orientation of the university and the quality of university research and the rate of innovation of the region in which the university is involved, representing, respectively, the internal and external context.

More specifically, based on the development of an index to measure the university's ability to promote the economic and entrepreneurial exploitation of academic research, data relating to Italian situation show that most of the Italian universities have started the development path toward the third mission promoting initiatives aimed to support the exploitation of research results and also reaching interesting results. But at the same time, from the analysis emerges a very differentiate picture among universities in terms of entrepreneurial orientation development. We can find, in fact, universities actively involved in several activities aimed to promote technology transfer and universities focused only on a more limited area of activities and with a focus on specific subjects (spin-off, patents, incubators, and so on). These results are probably an expression of different interpretation by universities of their entrepreneurial role, and probably, it reflects a different level of awareness about the role of the university technology transfer in the modern society. 


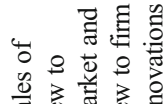

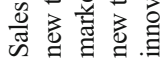

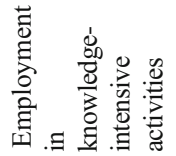

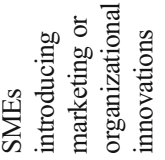

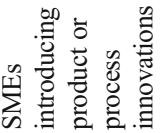

节. :

일

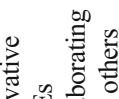

宣致产

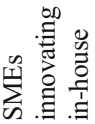

के

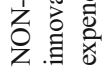

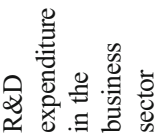

鳝

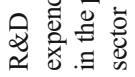

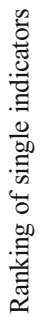

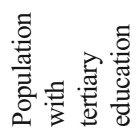

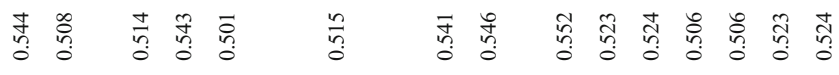

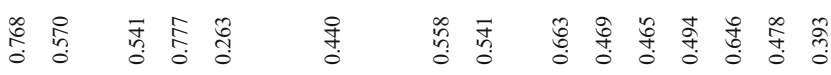

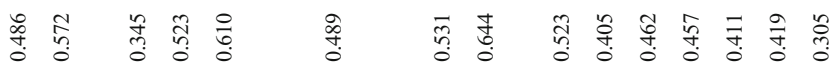

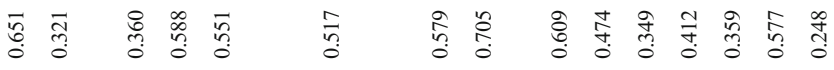

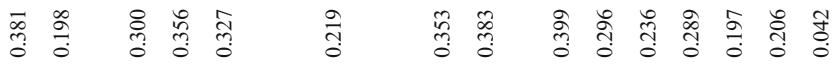

居年

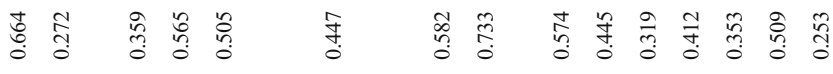

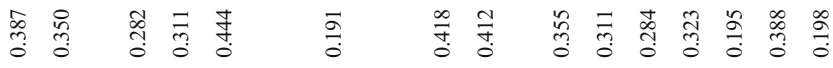

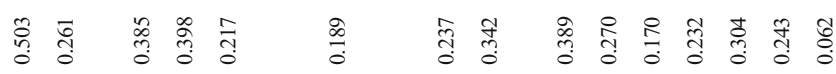

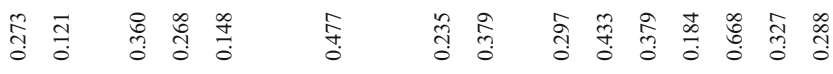

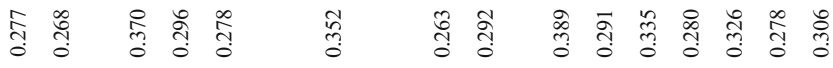

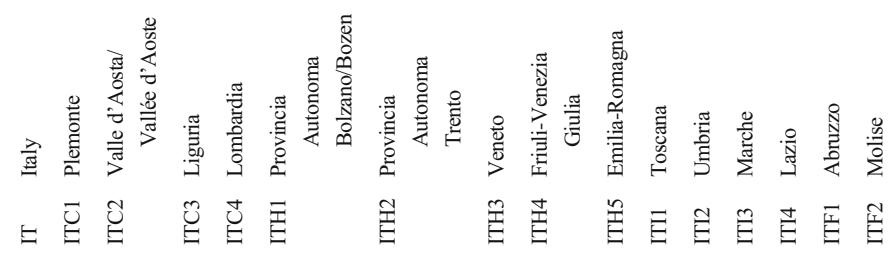




$$
\text { 留 }
$$


About factors influencing the entrepreneurial orientation of universities, from the analysis emerges that best results are obtained by those universities that are at the same time "champions" in research activities and are also involved in an "innovative context," that is, in general terms able to interact with the university and is able to provide the suitable conditions for the exploitation and valorization of research developed in the universities.

The results obtained are consistent with the literature on the role of academic research and its quality in the development of technology transfer processes (Hewitt-Dundas 2012; Caldera and Debande 2010). As stated by some authors (Chang et al. 2009; HewittDundas 2012) to promote the valorization of academic research, "it is necessary to build up a university as a dual structural organization that allows pursuing research excellence and research commercialization at the same time" (Chang et al. 2009, p. 945).

On the other hand, our research is in line with studies that highlight that effectiveness of technology transfer initiatives and instruments adopted is not independent from the context in which universities operate and are involved (Guerrero and Urbano 2012; Friedman and Silberman 2003).

In other terms, our results show that the effectiveness of entrepreneurial university is more than a technical matter but a more complex issue regarding the operations, the institutional context like culture, economy, or the regulatory framework, and the general purpose of the universities.

The effectiveness of technology transfer activities depends not only from the university activism but even more dependent from the National and Local context in which university is involved.

The prospects of the third mission and the effectiveness of efforts made by university are determined both by changes in the external environment and, above all, by the commitment developed toward the third mission by the university itself.

In fact, on one hand, it is necessary to develop, at a local and national level, an innovation system able to interact with the university to give continuity to actions promoted by them.

But, on the other side, it is necessary that technology transfer initiatives promoted by universities are not managed as single initiatives but they should be framed in the context of a global policy and a comprehensive strategy of the university aimed to develop the third mission.

Consistent with the academic literature that has studied the transformation of universities from a simple knowledge diffusion organization (Etzkowitz et al. 2000) to an intermediary in the entrepreneurial commercialization process of science and technology (Chen and Lin 2017), a strong relationship exists between university and ecosystem. The entrepreneurial university is able to promote academic success through entrepreneurship and create a vibrant entrepreneurial ecosystem (Fuster et al. 2019; Siegel and Wright 2015). However, the context in which the entrepreneurial university fits is very important because it acts as a multiplier for the creation of an entrepreneurial ecosystem (Carayannis et al. 2016).

\section{Implications and Future Research}

Our research has theoretical and practical implications. From a theoretical point of view, the study contributes to a better understanding of the most critical factors that 
condition the third mission of the university. More specifically, the research contributes to the understanding of the interaction among environmental and internal factors in the development of entrepreneurial universities (Klofsten et al. 2019; Guerrero and Urbano 2012).

From a practical point of view, our research has implications both for universities, management, and policy makers in the adoption of adequate measures able to promote and support the entrepreneurial mission of academia. From the university point of view, the research suggests first of all the necessity to mature a full awareness about its new role in society and for social and economic development. Furthermore, the research provides evidences about the necessity to adopt and implement a global and wellstructured strategy of technology transfer.

From the perspective of policy maker, the study highlights the importance to create an ecosystem of innovation able to promote and sustain the technology transfer processes of research from university to economic system. At the same time, the research suggests the necessity of an entrepreneurial and innovation strategy based on the full recognition of the role of universities such as an agent of the ecosystem of innovation.

The research has several limitations that create future area of investigation. First of all, we recognize the explorative nature of our study. The research relates to the Italian experience and this limits the generalization of results but at the same time, the Italian experience could be a meaningful example for other country with similar internal situation. Italy represents a peculiar context to study these activities due to the difference between the different local contexts. Consequently, it lends itself to be generalizable for those countries where internal differences are significant. An extended investigation comparing for example the Italian situation with the experience of other European and non-European universities could be useful to validate our results.

Second, the research considers some factors able to influence the entrepreneurial orientation of universities: probably, there are many other factors, both internal and external to the universities that need to be considered in analyzing the evolution of universities toward third mission.

Funding Open access funding provided by Università degli Studi di Salerno within the CRUI-CARE Agreement.

Open Access This article is licensed under a Creative Commons Attribution 4.0 International License, which permits use, sharing, adaptation, distribution and reproduction in any medium or format, as long as you give appropriate credit to the original author(s) and the source, provide a link to the Creative Commons licence, and indicate if changes were made. The images or other third party material in this article are included in the article's Creative Commons licence, unless indicated otherwise in a credit line to the material. If material is not included in the article's Creative Commons licence and your intended use is not permitted by statutory regulation or exceeds the permitted use, you will need to obtain permission directly from the copyright holder. To view a copy of this licence, visit http://creativecommons.org/licenses/by/4.0/.

\section{References}

Algieri, B., Aquino, A., \& Succurro, M. (2013). Technology transfer offices and academic spin-off creation: the case of Italy. The Journal of Technology Transfer, 38(4), 382-400. 
Anvur - Agenzia Nazionale di Valutazione del sistema Universitario e della Ricerca (2013). Rapporto finale Anvur. Valutazione della Qualità della Ricerca 2004-2010.

Balderi, C., Daniele, C., \& Piccaluga, A. (2012). Gli uffici di trasferimento tecnologico delle università italiane: numeri ma non solo numeri. Economia e Politica Industriale.

Banga, K., \& te Velde, D. W. (2019). Preparing developing countries for the future of work: understanding skills-ecosystem in a digital era. Pathways Commission.

Barba-Sánchez, V., \& Atienza-Sahuquillo, C. (2018). Entrepreneurial intention among engineering students: the role of entrepreneurship education. European Research on Management and Business Economics, 24(1), 53-61.

Bengoa, A., Maseda, A., Iturralde, T., \& Aparicio, G. (2020). A bibliometric review of the technology transfer literature. The Journal of Technology Transfer, 1-37.

Blair, D. M., \& Hitchens, D. M. (1998). Campus companies-UK and Ireland. Aldershot: Ashgate.

Bonaccorsi, A., \& Daraio, C. (Eds.). (2007). Universities and strategic knowledge creation: specialization and performance in Europe. Edward Elgar Publishing.

Bradley, S. R., Hayter, C. S., \& Link, A. N. (2013). Models and methods of university technology transfer. Foundations and Trends ${ }^{\circledR}$ in Entrepreneurship, 9(6), 571-650.

Brett, A., Gibson, D., \& Smilor, R. (1991). University spin-off companies. Maryland: Rowman and Littlefield Publishing Inc..

Caldera, A., \& Debande, O. (2010). Performance of Spanish universities in technology transfer: an empirical analysis. Research Policy, 39(9), 1160-1173.

Carayannis, E. G., Provance, M., \& Grigoroudis, E. (2016). Entrepreneurship ecosystems: an agent-based simulation approach. The Journal of Technology Transfer, 41(3), 631-653.

Carlesi, A., Mariani, G., \& Scarfò, A. (2017). Academic spin-offs for the local economy growth. Corporate Ownership \& Control, 350.

Cesaroni, F., \& Gambardella, A. (2001). Trasferimento tecnologico e gestione della proprietà intellettuale nel sistema della ricerca in Italia. Pisa: LEM-Sant'Anna School of Advanced Studies.

Cesaroni, F., Moscara, P., \& Piccaluga, A. (2005). Le imprese spin-off della ricerca in Italia: modelli di sviluppo e percorsi di crescita. Piccola impresa-Small business, 1, 81-126.

Chang, Y. C., Yang, P. Y., , Chen, M. (2009). The determinants of academic research commercial performance: towards an organizational ambidexterity perspective. Research Policy, 38, 936-946.

Chen, S. H., \& Lin, W. T. (2017). The dynamic role of universities in developing an emerging sector: a case study of the biotechnology sector. Technological Forecasting and Social Change, 123, 283-297.

Clark, B. R. (1998). Creating entrepreneurial universities. Oxford: Pergamon.

Clark, B. R. (2004). Delineating the character of the entrepreneurial university. Higher Education Policy, 17(4), 355-370.

Clarysse, B., \& Moray, N. (2004). A process study of entrepreneurial team formation: the case of a researchbased spin-off. Journal of Business Venturing, 19(1), 55-79.

D'Este, P., \& Perkmann, M. (2011). Why do academics engage with industry? The entrepreneurial university and individual motivations. The Journal of Technology Transfer, 36(3), 316-339.

Dabić, M. (2019, 2019). Entrepreneurial University in the European Union-EU in the EU. Journal of Knowledge Economy. https://doi.org/10.1007/s13132-018-0579-0.

Dalmarco, G., Hulsink, W., \& Blois, G. V. (2018). Creating entrepreneurial universities in an emerging economy: evidence from Brazil. Technological Forecasting and Social Change, 135, 99-111.

Deeds, D. L., DeCarolis, D. M., \& Coombs, J. E. (1998). Firm-specific resources and wealth creation in hightechnology ventures: evidence from newly public biotechnology firms. Entrepreneurship Theory and Practice, 22(3), 55-73.

Di Gregorio, D., \& Shane, S. (2003). Why do some universities generate more start-ups than others? Research Policy, 32(2), 209-227.

Dooley, L., \& Kirk, D. (2007). University-industry collaboration. European Journal of Innovation Management, 10(3), 316-332.

Duval-Couetil, N. (2013). Assessing the impact of entrepreneurship education programs: challenges and approaches. Journal of Small Business Management, 51(3), 394-409.

Elia, G., Secundo, G., \& Passiante, G. (2017). Pathways towards the entrepreneurial university for creating entrepreneurial engineers: an Italian case. International Journal of Entrepreneurship and Innovation Management, 21(1-2), 27-48.

Etzkowitz, H. (1993). Technology transfer: the second academic revolution. Technology Access Report, 6, 7.

Etzkowitz, H. (2003a). Innovation in innovation: the triple helix of university-industry-government relations. Social Science Information, 42(3), 293-337. 
Etzkowitz, H. (2003b). The European entrepreneurial university: an alternative to the US model. Industry and Higher Education, 17(5), 325-335.

Etzkowitz, H. (2004). The evolution of the entrepreneurial university. International Journal of Technology and Globalisation, 1(1), 64-77.

Etzkowitz, H. (2017). Innovation Lodestar: the entrepreneurial university in a stellar knowledge firmament. Technological Forecasting and Social Change, 123, 122-129.

Etzkowitz, H. (2019). The second academic revolution: antecedents and consequences of academic entrepreneurship. In Handbook of Universities and Regional Development. Edward Elgar Publishing.

Etzkowitz, H., \& Leydesdorff, L. (1995). The triple helix-university-industry-government relations: a laboratory for knowledge-based economic development. Easst Review, 14(1), 14-19.

Etzkowitz, H., \& Leydesdorff, L. (2000). The dynamics of innovation: from National System and "mode 2" to a triple helix of university-industry-government relations. Research Policy, 29(2), 109-123.

Etzkowitz, H., Dzisah, J., Ranga, M., \& Zhou, C. (2007). Special feature: the triple helix model for innovation. Tech Monitor, 14.

Etzkowitz, H., Germain-Alamartine, E., Keel, J., Kumar, C., Smith, K. N., \& Albats, E. (2019). Entrepreneurial university dynamics: structured ambivalence, relative deprivation and institutionformation in the Stanford innovation system. Technological Forecasting and Social Change, 141, 159171.

Etzkowitz, H., Webster, A., Gebhardt, C., \& Cantisano Terra, B. R. (2000). The future of the university and the university of the future: evolution of ivory tower to entrepreneurial paradigm. Research Policy, 29, 313-330.

European Commission (2002). Final report of the expert group "Best Procedure”, project on education and training for entrepreneurship. Brussels: European Commission.

European Union. (2014). Regional Innovation Scoreboard, 2014.

Fayolle, A. (Ed.). (2007). Handbook of research in entrepreneurship education: a general perspective (Vol. 1). Edward Elgar Publishing.

Fayolle, A., \& Redford, D. T. (Eds.). (2014). Handbook on the entrepreneurial university. Cheltenham: Edward Elgar Publishing.

Feldman, M. P. (2001). The entrepreneurial event revisited: firm formation in a regional context. Industrial and Corporate Change, 10(4), 861-891.

Feldman, M., Siegel, D. S., \& Wright, M. (2019). New developments in innovation and entrepreneurial ecosystems. Industrial and Corporate Change, 28(4), 817-826.

Fernandez-Alles, M., Diánez-González, J. P., Rodríguez-González, T., \& Villanueva-Flores, M. (2018). TTO characteristics and university entrepreneurship: a cluster analysis. Journal of Science and Technology Policy Management.

Fini, R., Grimaldi, R., Marzocchi, G. L., \& Sobrero, M. (2011). Complements or substitutes? The role of universities and local context in supporting the creation of academic spin-off. Research Policy, 40(8), 1113-1127.

Fini, R., Grimaldi, R., Marzocchi, G. L., \& Sobrero, M. (2012). The determinants of corporate entrepreneurial intention within small and newly established firms. Entrepreneurship Theory and Practice, 36(2), 387414.

Fiore, E., Sansone, G., \& Paolucci, E. (2019). Entrepreneurship education in a multidisciplinary environment: evidence from an entrepreneurship programme held in Turin. Administrative Sciences, 9(1), 28.

Friedman, J., \& Silberman, J. (2003). University technology transfer: do incentives, management, and location matter? Journal of Technology Transfer, 28, 17-30.

Fryges, H., \& Wright, M. (2014). The origin of spin-offs: a typology of corporate and academic spin-offs. Small Business Economics, 43(2), 245-259.

Fuster, E., Padilla-Meléndez, A., Lockett, N., \& del-Águila-Obra, A. R. (2019). The emerging role of university spin-off companies in developing regional entrepreneurial university ecosystems: the case of Andalusia. Technological Forecasting and Social Change, 141, 219-231.

Gibb, A. (2005). The future of entrepreneurship education-determining the basis for coherent policy and practice. The dynamics of learning entrepreneurship in a cross-cultural university context. Ed. P. Kyrö and C. Carrier. University of Tampere: Research Centre for Vocational and Professional Education.

Good, M., Knockaert, M., Soppe, B., \& Wright, M. (2019). The technology transfer ecosystem in academia. An organizational design perspective. Technovation, 82, 35-50.

Grimaldi, R., \& Grandi, A. (2001). The contribution of university business incubators to new knowledgebased ventures. Industry and Higher Education, 15(4), 239-250.

Guerrero, M. (2008). The creation and development of entrepreneurial universities in Spain: an institutional approach (Doctoral dissertation, Universitat Autònoma de Barcelona). 
Guerrero, M., \& Urbano, D. (2007). Entrepreneurial university: the case of Autonomous University of Bercelona. UAB Research Paper.

Guerrero, M., \& Urbano, D. (2012). The development of entrepreneurial university. Journal of Technology Transfer, 37, 43-74.

Guerrero, M., Urbano, D., \& Fayolle, A. (2016a). Entrepreneurial activity and regional competitiveness: evidence from European entrepreneurial universities. The Journal of Technology Transfer, 41(1), 105131.

Guerrero, M., Urbano, D., Fayolle, A., Klofsten, M., \& Mian, S. (2016b). Entrepreneurial universities: emerging models in the new social and economic landscape. Small Business Economics, 47(3), 551-563.

Harrison, R. T., \& Leitch, C. (2010). Voodoo institution or entrepreneurial university? Spin-off companies, the entrepreneurial system and regional development in the UK. Regional Studies, 44(9), 1241-1262.

Heirman, A., \& Clarysse, B. (2004). How and why do research-based start-ups differ at founding? A resourcebased configurational perspective. The Journal of Technology Transfer, 29(3-4), 247-268.

Hellmann, T., \& Puri, M. (2002). Venture capital and the professionalization of start-up firms: empirical evidence. The Journal of Finance, 57(1), 169-197.

Hewitt-Dundas, N. (2012). Research intensity and knowledge transfer activity in UK universities. Research Policy, 41(2), 262-275.

Holden, T., \& Goldstein, B. (2010). Engines of innovation: the entrepreneurial university in the twenty-first century. New England Journal of Entrepreneurship, 14(2), 81-83.

Jacob, M., Lundqvist, M., \& Hellsmark, H. (2003). Entrepreneurial transformations in the Swedish University system: the case of Chalmers University of Technology. Research Policy, 32(9), 1555-1568.

Joia, L. A., \& Lemos, B. (2010). Relevant factors for tacit knowledge transfer within organisations. Journal of Knowledge Management.

Kim, B., Kim, M., \& Kim, E. (2017). Characteristics of codified knowledge and replication-imitation speed differentials. Management Decision., 55, 1785-1801.

Kirby, J. (2005). Entrepreneurial initiatives at public liberal arts and general baccalaureate colleges. ProQuest (UMI No. 3170925).

Klepper, S. (2007). Disagreements, spinoffs, and the evolution of Detroit as the capital of the US automobile industry. Management Science, 53(4), 616-631.

Klofsten, M., Fayolle, A., Guerrero, M., Mian, S., Urbano, D., \& Wright, M. (2019). The entrepreneurial university as driver for economic growth and social change - key strategic challenges. Technological Forecasting and Social Change, 141, 149-158.

Kortum, S., \& Lerner, J. (1998). Does venture capital spur innovation? (No. w6846). National bureau of economic research.

Lee, P. (2020). Tacit knowledge and university-industry technology transfer. In Research Handbook on Intellectual Property and Technology Transfer. Edward Elgar Publishing.

Lockett, A., Siegel, D., Wright, M., \& Ensley, M. D. (2005). The creation of spin-off firms at public research institutions: managerial and policy implications. Research Policy, 34(7), 981-993.

Martin, S., \& Scott, J. T. (2000). The nature of innovation market failure and the design of public support for private innovation. Research Policy, 29(4), 437-447.

Mian, S. (1994). US university-sponsored technology incubators: an overview of management, policies and performance. Technovation, 14(8), 515-528.

Mian, S. (1996). Assessing value-added contributions of university technology business incubators to tenant firms. Research Policy, 25(3), 325-335.

Mian, S. (2011) University's involvement in technology business incubation: what theory and practice tell us?, International Journal of Entrepreneurship and Innovation Management, 13.

Mosey, S., Guerrero, M., \& Greenman, A. (2017). Technology entrepreneurship research opportunities: insights from across Europe. The Journal of Technology Transfer, 42(1), 1-9.

Mueller, P. (2006). Exploring the knowledge filter: how entrepreneurship and university-industry relationships drive economic growth. Research Policy, 35, 1499-1508.

Muscio, A. (2010). What drives the university use of technology transfer offices? Evidence from Italy. Journal of Technology Transfer, 35(2), 181-202.

Muscio, A., Quaglione, D., \& Ramaciotti, L. (2016). The effects of university rules on spinoff creation: the case of academia in Italy. Research Policy, 45(7), 1386-1396.

Mustar, P., \& Wright, M. (2010). Convergence or path dependency in policies to foster the creation of university spin-off firms? A comparison of France and the United Kingdom. The Journal of Technology Transfer, 35(1), 42-65. 
Napolitano, M. R., \& Riviezzo, A. (2008). The institutional education and training for entrepreneurship development in the Italian universities. International Journal of Entrepreneurship and Innovation Management, 8(6), 665-685.

Netval - Italian Network for the valorization of public research (2018). XIV Rapporto Netval La rete del trasferimento tecnologico si rafforza con la clinical innovation (Eds L. Ramaciotti, C. Daniele). Pisa: Edizioni ETS.

O'Shea, R. P., Allen, T. J., Chevalier, A., \& Roche, F. (2005). Entrepreneurial orientation, technology transfer and spinoff performance of U.S. universities. Research Policy, 34(7), 994-1009.

O’Shea, R. P., Allen, T. J., Morse, K. P., O’Gorman, C., \& Roche, F. (2007). Delineating the anatomy of an entrepreneurial university: The Massachusetts Institute of Technology Experience. $R \& D$ Management, 37(1), 1-16.

O’Shea, R. P., Chugh, H., \& Allen, T. J. (2008). Determinants and consequences of university spinoff activity: a conceptual framework. The Journal of Technology Transfer, 33(6), 653-666.

Parente R., \& Cerrato D. (2002). Available resources - necessary resources: closing the gap. Mediators'role in establishing resources flows between large and new enterprises. Paper presented at EFMD Conference: New frontiers between small and large firms, Ceram Sophia-Antipolis, available on http://eprints.stoa. it/184.

Parente, R., Feola, R., Cucino, V., \& Catolino, G. (2015). Visibility and reputation of new entrepreneurial projects from academia: the role of start-up competitions. Journal of the Knowledge Economy, 6(3), 551567.

Perez, M. P., \& Sánchez, A. M. (2003). The development of university spin-offs: early dynamics of technology transfer and networking. Technovation, 23(10), 823-831.

Petruzzelli, A. M., \& Murgia, G. (2019). University-industry collaborations and international knowledge spillovers: a joint-patent investigation. The Journal of Technology Transfer, 1-26.

Phillips, F. (2018). The sad state of entrepreneurship in America: what educators can do about it. Technological Forecasting and Social Change, 129, 12-15.

Piccaluga, A. (2001). La valorizzazione della ricerca scientifica: come cambia la ricerca pubblica e quella industriale. Milano: FrancoAngeli.

Ranga, L., Debackere, K., \& Tunzelmann, N. (2003). Entrepreneurial universities and the dynamics of academic knowledge production: a case study of basic vs. applied research in Belgium. Scientometrics, 58(2), 301-320.

Riviezzo, A., \& Napolitano, M. R. (2010). Italian universities and their third mission: a longitudinal analysis of the organization and education renewal towards the 'entrepreneurial university' model. Industry \& Higher Education, 3, 227-236.

Riviezzo, A., Liñán, F., \& Napolitano, M. R. (2017). Assessing the entrepreneurial orientation of university departments. A comparative study between Italy and Spain. In Entrepreneurial Universities (pp. 35-46). Springer, Cham.

Rizzo, U. (2015). Why do scientists create academic spin-offs? The influence of the context. The Journal of Technology Transfer, 40(2), 198-226.

Roberts, E. B. (1991). Entrepreneurs in high technology: Lessons from MIT and beyond. New York, US: Oxford University Press.

Roberts, E. B., \& Malone, D. E. (1996). Policies and structures for spinning off new companies from research and development organizations. $R \& D$ Management, 26(1), 17-48.

Rothaermel, F. T., \& Thursby, M. (2005). University-incubator firm knowledge flows: assessing their impact on incubator firm performance. Research Policy, 34(3), 305-320.

Rothaermel, F. T., Agung, S. D., \& Jiang, L. (2007). University entrepreneurship: a taxonomy of the literature. Industrial and Corporate Change, 16(4), 691-791.

Sánchez-Barrioluengo, M., \& Benneworth, P. (2019). Is the entrepreneurial university also regionally engaged? Analysing the influence of university's structural configuration on third mission performance. Technological Forecasting and Social Change, 141, 206-218.

Schulte, P. (2004). The entrepreneurial university: a strategy for institutional development. Higher Education in Europe, 29(2), 187-191.

Shane, S. A. (2004). Academic entrepreneurship: university spinoffs and wealth creation. Edward Elgar Publishing.

Shane, S., \& Stuart, T. (2002). Organizational endowments and the performance of university start-ups. Management Science, 48(1), 154-170.

Siegel, D. S., \& Wright, M. (2015). Academic entrepreneurship: time for a rethink? British Journal of Management, 26(4), 582-595. 
Siegel, D. S., Wright, M., \& Lockett, A. (2007). The rise of entrepreneurial activity at universities: organizational and societal implications. Industrial and Corporate Change, 16, 489-504.

Sperrer, M., Müller, C., \& Soos, J. (2016). The concept of the entrepreneurial university applied to universities of technology in Austria: already reality or a vision of the future? Technology Innovation Management Review, 6(10), 37-44.

Sporn, B. (2001). Building adaptive universities: emerging organisational forms based on experiences of European and US universities. Tertiary Education \& Management, 7(2), 121-134.

Steffensen, M., Rogers, E. M., \& Speakman, K. (2000). Spin-offs from research centers at a research university. Journal of Business Venturing, 15(1), 93-111.

Stokes, D., \& Wilson, N. C. (2010). Entrepreneurship and marketing education: time for the road less travelled? International Journal of Entrepreneurship and Innovation Management, 11(1), 95-108.

Trequattrini, R., Lombardi, R., Lardo, A., \& Cuozzo, B. (2015). The impact of entrepreneurial universities on regional growth: a local intellectual capital perspective. Journal of the Knowledge Economy, 9(1), 199211.

Turner, T., \& Gianiodis, P. (2018). Entrepreneurship unleashed: understanding entrepreneurial education outside of the business school. Journal of Small Business Management, 56(1), 131-149.

Von Zedtwiz, M., \& Grimaldi, R. (2006). Key success factors of incubator business models: results of an empirical investigation in Italy. Journal of Technology Transfer, 31(4), 459-468.

Publisher's Note Springer Nature remains neutral with regard to jurisdictional claims in published maps and institutional affiliations. 